\title{
Determination of Antioxidant Activity and Physico- Chemicals Characteristics of Fortified Yogurt Powder by Super Red Dragon (Hylocereus Polyrhizus) Fruit Peel Powder
}

\author{
Florentina Supriyanti ${ }^{1}$, Zackiyah $^{2}$, Fiona Finandia ${ }^{3}$ \\ \{florentinasupriyanti@yahoo.co.id ${ }^{1}$, zackiyah_da@upi.edu ${ }^{2}$,ffinandia@gmail.com ${ }^{3}$ \} \\ Chemistry Study Program Department of Chemistry Education Faculty of Mathematics and Natural \\ Sciences Education Indonesian education university Bandung 40514, Indonesia ${ }^{1,2,3}$
}

\begin{abstract}
This research aims to investigate the antioxidant activity and physicochemical characteristics of yogurt powder fortified by the peel of super red dragon (Hylocereus costaricensis) fruit. Methods include the making of super red dragon fruit peel powder, making yogurt, fortification of yogurt using super red dragon fruit peel powder and freezedrying. The analysis consists of antioxidant activity with the DPPH method and Physicochemicals characteristics include water content by gravimetric method, ash content by ashing method and $\mathrm{pH}$ by potentiometric method. Produced yogurt without fortification (F0) and three fortified yogurt variants F1, F2 and F3 with 10\%; 20\%; 30\% successive fortification. The super red dragon fruit peels had antioxidant activity $93.08 \% \pm 2.51$; powdered yogurt before fortification $15.86 \% \pm 3.39$ while F1, F2 and F3 fortified powdered yogurt were $63.69 \% \pm 1.70 ; 76.33 \% \pm 2.79$ and $92.67 \% \pm 1.61$ respectively. The water content of powdered yogurt before fortification was greater than fortified yogurt. The ash content of yogurt before fortification and fortified powdered yogurt are greater than the value of standard ash content. The $\mathrm{pH}$ value of yogurt powder before fortification and fortified yogurt is in the $\mathrm{pH}$ range of yogurt.
\end{abstract}

Keywords: Antioxidant Activity, Super Red Dragon Fruit Peel, Yogurt Powder

\section{Introduction}

Today's society tends to be aware to live a healthy lifestyle through the consumption of healthy foods or drinks. One example of a healthy drink is yogurt. Yogurt is a processed product of fermented milk using two types of bacterial culture, namely Streptococcus thermophilus and Lactobacillus bulgaricus [1]. Yogurt has various health benefits, such as increasing lactose absorption, reducing lactose intolerance, antimicrobial activity, increasing the ability to digest proteins and lipids, and can stimulate the immune system [2]. However yogurt has a short shelf life, so an increase in the shelf life of yogurt can be obtained through drying until yogurt powder is obtained.

The main objective of the drying process is to maintain the product in the form of highquality powder without the need for cooling [3]. The freeze-drying method is the most suitable method to maintain food quality because it does not change the taste and maintain nutrients in food [4]. Fresh yogurt or yogurt powder is generally consumed because it is used as a source of 
protein. Yogurt contains high protein, but low in vitamin $\mathrm{C}$, the content of vitamin $\mathrm{C}$ in yogurt is only $4 \mathrm{mg} / 100 \mathrm{~g}$, while vitamin $\mathrm{C}$ can function as an antioxidant.[5] The addition of antioxidant compounds is needed to increase the benefits of yogurt. Yogurt with additional antioxidants from natural sources will make yogurt have more benefits [6]. The vitamin $\mathrm{C}$ content of dragon fruit peels reaches $9.4 \mathrm{mg} / 100 \mathrm{~g}$ while the flesh of the fruit is $8-9 \mathrm{~g}$ per 100g. [7].

Super red dragon fruit peels contain alkaloids, terpenoids, flavonoids, and phenolics [8]. Super red dragon fruit contains antioxidants both in flesh and peel. The antioxidant activity found in super red dragon fruit peels is higher than the antioxidant activity found in the flesh of the fruit, so the super red dragon fruit peels need to be developed as a source of natural antioxidants [9]

This is in accordance with research conducted by Nurliyana, which is stated in $1 \mathrm{mg} / \mathrm{mL}$ super red dragon fruit skin can keep free radicals as much as $83.48 \% \pm 1.02$, while for $1 \mathrm{mg} /$ $\mathrm{mL}$ the fruit flesh can be used free of radicals by $27,45 \% \pm 5.03$ [10] Therefore fortification of dragon fruit peels in yogurt will increase the antioxidant content of yogurt. The Wahyuni's research, super red dragon fruit flesh is used in making jenang [11] and in Sari and Rohmah research, super red dragon fruit meat is used as additional material in making nuggets [12].

The utilization of super red dragon fruit peel as a source of antioxidants in the production of yogurt powder has never been done. This study aims to determine the antioxidant activity and physicochemical properties of fortified yogurt powder by super red dragon (Hylocereus polyrhizus) fruit peel powder.

\section{Material and Method}

\subsection{Material}

The ingredients in this research include whole milk, super red dragon fruit peel, skim milk, aquades, yogurt starter containing Lactobacillus bulgaricus and Streptococcus thermophilus, Magnesium powder, concentrated Hydrochloric acid Merck KGaA, Sodium hydroxide Merck KGaA, methanol Merck KGaA, Chloroform Merck KGaA, Mayer reagents, glacial Acetic Acid Merck KGaA, concentrated Sulfuric acid Merck KGaA, Iron(III) Chloride , and DPPH (2,2diphenyl-1-picrylhydrazyl) Aldrich reagents.

\subsection{Method}

Making Super Red Dragon Fruit Peel Powder. Super red dragon fruit is sorted, washed and peeled. The super red dragon fruit skin is dried in the open air, mashed and filtered using a 100 mesh size filtering. Super red dragon fruit skin powder is sterilized using UV-C lamps. Then the phytochemical test and antioxidant activity test were carried out.

Phytochemical Test. The phytochemical test of super red dragon fruit peel was performed using the Sangi method. [13]. Samples of super red dragon fruit peel powder identified phytochemical content with color reagents aimed to determine the type of secondary metabolite compounds. Phytochemical tests include flavonoid testing with the addition of $\mathrm{Mg}$ powder and a few drops of concentrated $\mathrm{HCl}$, an alkaloid test with the addition of chloroform and Mayer reagents, a terpenoid and steroid test with the addition of glacial acetic acid and concentrated 
sulfuric acid, a tannin test with the addition of $\mathrm{FeCl} 3$, and a test for betacyanin compounds $\mathrm{NaOH}$.

Making Yogurt. Making yogurt using the method carried out by Teguh [14] and Kennas [15]. Pure milk is added with $2 \%$ skim milk. Milk pasteurized at $85^{\circ} \mathrm{C}$ for 30 minutes, and then cooled to a temperature of $\pm 42^{\circ} \mathrm{C}$, after that a starter was added consist of Streptococcus Thermophillus and Lactobacillus Bulgaricus 5\%. The mixture was incubated at $42{ }^{\circ} \mathrm{C}$ for 5 hours, then put in the refrigerator until it will be used.

Yogurt Fortification. Super red dragon fruit peel powder was added to yogurt with a super red dragon fruit peel powder percentage of 10\% (F1); 20\% (F2); 30\% (F3). The mixture was stirred until homogeneous and freeze-dried for 2 days, kept in closed cupboards until it will be used. Products without the addition of super red dragon fruit peel powder are used as control yogurt (F0).

Antioxidant Activity Test. The determination of antioxidant activity was carried out using the method according to Garcia [16]. DPPH solution is prepared by dissolving DPPH in methanol. Super red dragon fruit peel powder and fortified yogurt were tested for antioxidant activity by making sample solutions, blanks, and controls.

Making the sample solution is done by mixing the sample, methanol solvent, and DPPH solution. A blank solution is made by mixing the sample with a methanol solvent. Whereas the control solution was made by mixing methanol solvent with DPPH solution. Then each mixture was shaken and incubated for 100 minutes. Absorbance measurements were performed using a $\mathrm{UV}-\mathrm{V}$ is spectrophotometer at a wavelength of $517 \mathrm{~nm}$. Antioxidant activity is calculated based on the following equation (1):

$\%$ Antioxidant Activity $=100-[(($ Abs sample-Abs blank $)) /($ Abs control $)$

Physico-chemicals characteristics. In this section, will describe about Water Content, Ash Content, and Degree of Acidity ( $\mathrm{pH})$.

Water Content. The water content test is carried out using the method according to SNI [17]. Yogurt fortified powder of super red dragon fruit skin is weighed 1-3 grams and put into a dried cup and its weight is known. Then a sample of the yogurt powder fortified the super red dragon fruit skin in a cup is dried in the oven at $105^{\circ} \mathrm{C}$ for 3 hours. Then cooled in a desiccator and weighed. Moisture content can be calculated with the following equation (2):

$$
\text { Water content }(\%)==\frac{\left(W_{1}-W_{2}\right)}{\left(W_{1}-W_{0}\right)} \times 100
$$

Information:

$\mathrm{W} 0=$ empty cup mass

$\mathrm{W} 1$ = mass of the cup and sample before drying

$\mathrm{W} 2$ = cup mass and sample after drying

Ash Content. Ash content test was carried out according to SNI [18]. Yogurt powder fortified super red dragon fruit skin weighed 1-3 grams and put in a dried cup and its weight is known. The fortified yogurt powder by super red dragon fruit peel in a cup is dried in an electric furnace using a temperature of $550^{\circ} \mathrm{C}$ until complete graying. Ash content can be calculated using the following equation (3):

$$
\text { Ash content }(\%)=\frac{W_{1}-W_{2}}{W} \times 100
$$




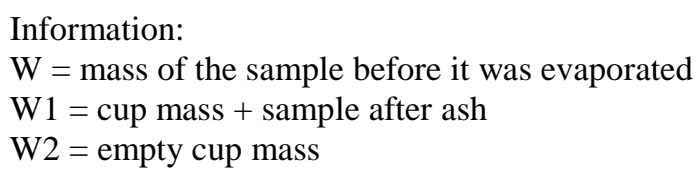

Degree of Acidity (pH). Measurement of pH was carried out to determine the acidity of a solution. The $\mathrm{pH}$ measurements were carried out using the potentiometric method with a $\mathrm{pH}$ meter and the material needed to be $\pm 40 \mathrm{~mL}$ of sample. The $\mathrm{pH}$ meter is calibrated first using a $\mathrm{pH} 7$ buffer solution and a $\mathrm{pH} 4$ buffer solution then the electrode in the $\mathrm{pH}$ meter is dipped in a beaker containing the sample. Wait a while until the $\mathrm{pH}$ of the sample is stable then the results of the $\mathrm{pH}$ measurement test will be read on the $\mathrm{pH}$ meter screen [19].

\section{Results and Discussion}

Super red dragon fruit (Hylocereus costaricensis) of 1000 grams is dried for \pm 1 week aimed to reduce water content. Super red dragon fruit peel that has been mashed and sifted with 100 mesh filter size. The results are super red dragon fruit skin powder as much as $8.03 \%$ of the weight. Phytochemical test results showed super red dragon fruit peel powder containing flavonoids, alkaloids, terpenoids, tannins, and betacyanin.

Powder yogurt production begins with the addition of $2 \%$ skim milk with the aim to increase the total solids produced after the freeze-drying process. Pasteurization was carried out at $85^{\circ} \mathrm{C}$ for 30 minutes, aiming to kill pathogenic bacteria so that the culture could grow up optimum. During the pasteurization process, stirring is carried out to avoid coagulation of milk which causes the mixture to become homogeneous. Pasteurized milk was cooled to $42^{\circ} \mathrm{C}$, inoculated using Lactobacillus bulgaricus and Streptococcus thermophillus in a ratio of 1: 1 . Lactic acid bacteria were added as much as $5 \%$ of the volume of milk, then incubated at $42^{\circ} \mathrm{C}$ for 5 hours [15]. The resulting yogurt is a rather thick white liquid.

Yogurt produced, fortified with super red dragon fruit skin powder that has been sterilized using a UV-C lamp. Sterilization is done to kill pathogenic bacteria found in super red dragon fruit skin powder without damaging compounds that act as antioxidants. UV-C lamps with wavelengths of 240-260 $\mathrm{nm}$ are used as alternatives to sanitation and have been accepted for use as disinfectants in food products [20].

Fortified yogurt products are made in 3 variants there are F1, F2 and F3 respectively with the addition of super red dragon fruit peel powder $10 \% ; 20 \% ; 30 \%$ and F0 which are yogurt products without the addition of super red dragon fruit skin powder. Yogurt fortification results show a significant color difference. This is due to the super red-pink dragon skin powder color so that $\mathrm{F} 3$ yogurt has the reddest color compared to $\mathrm{F} 2$ and $\mathrm{F} 1$.

The freeze-drying process aims to eliminate the water content in fortified yogurt and control yogurt so that the resulting product is a powdered yogurt. The freeze-drying method was chosen because it is a method that has advantages in maintaining the quality of the drying product, especially for yogurt products that contain lactic acid bacteria that are not resistant to heat. Yogurt powder produced has a dry weight percentage ranging from 12.29-15. 88\%. Mass yield and percent dry weight of fortified yogurt powder super red and without fortification can be seen in Table 1. 
Table 1. Mass and percent mass of dry yogurt powder fortified and without fortification.

\begin{tabular}{cccc}
\hline Sample & Wet Mass (gram) & Dry Mass (gram) & Dry Mass (\%) \\
\hline F0 & 500 & 61,4483 & 12,29 \\
F1 & 500 & 67,5361 & 13,51 \\
F2 & 500 & 73,1537 & 14,63 \\
F3 & 500 & 79,3827 & 15,88 \\
\hline
\end{tabular}

Dry mass results obtained are in the same range of values in research conducted by Kennas, which amounted to $12.56-22.63 \%$ [15].

Antioxidant activity test was carried out to determine the antioxidant activity found in super red dragon fruit peels and fortified yogurt powder super red dragon fruit peels. The antioxidant activity test was carried out using the DPPH method. Measurement of antioxidant activity was carried out using a UV-Vis spectrophotometer at a wavelength of $517 \mathrm{~nm}$. The results of the antioxidant activity test on super red dragon fruit peel and fortified yogurt powder super red dragon fruit peel are shown in Figure 1.

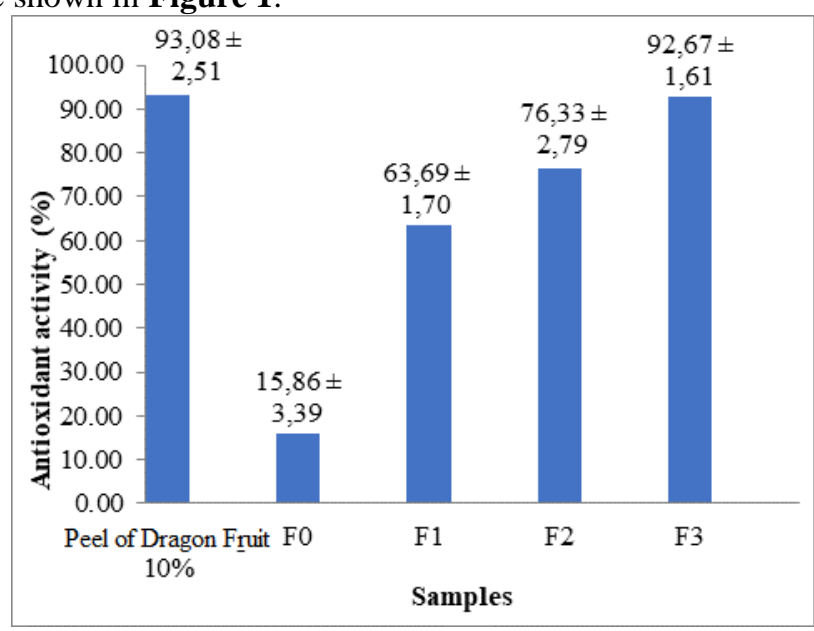

Fig.1. Antioxidant activity in super red dragon fruit peels and fortified yogurt powder without fortification.

Based on the antioxidant activity test using the DPPH method, the antioxidant activity of super red dragon fruit peels was $93.08 \%$. The high antioxidant activity of super red dragon fruit peels, because the super red dragon fruit peels contain various secondary metabolic compounds as antioxidants, besides of that super red dragon fruit peels also contain vitamin $\mathrm{C}$ which is also an antioxidant.

From Figure 1, it can be seen that the antioxidant activity of yogurt without the addition of super red dragon fruit peels is $15.68 \%$. While the value of the antioxidant activity of fortified yogurt super red dragon fruit peels ranged from 63.69 to $92.67 \%$. Based on these results, F3 has the highest antioxidant activity compared to F2, F1, and F0.

The water content test is done using the gravimetric method. The principle of the gravimetric method is based on the change in weight of a substance that is analyzed into another 
substance so that it can be known its permanent weight. The big difference before and after drying is the amount of water that evaporates. The results of the water content test on yogurt powder can be seen in Table 2 .

Table 2. Test results of water content and an ash content of fortified yogurt and without fortification.

Ash Content Moisture Samples

\begin{tabular}{|c|c|c|c|c|c|}
\hline & Samples & 11 & Water content & 2 & Ash Content \\
\hline$\overline{3}$ & F0 & 14 & $11,47 \% \pm 0,13$ & 15 & $4,87 \% \pm 0,86$ \\
\hline 6 & $\mathrm{~F} 1$ & 17 & $6,26 \% \pm 0,21$ & 18 & $6,52 \% \pm 0,11$ \\
\hline 9 & $\mathrm{~F} 2$ & 20 & $7,76 \% \pm 0,15$ & 21 & $6,88 \% \pm 0,06$ \\
\hline 2 & F3 & 23 & $7,86 \% \pm 0,23$ & 24 & $7,39 \% \pm 0,08$ \\
\hline
\end{tabular}

Based on the test results of water content in the fortified yogurt sample of super red dragon fruit peel, the water content value obtained is quite low. Low water content can increase the shelf life of powdered yogurt products. Powdered yogurt has a longer shelf life compared to liquid yogurt because the water content found in powdered yogurt is lower than the water content in liquid yogurt. The water content obtained in fortified powdered yogurt is in accordance with the results of research conducted by Herminiati [21].

Ash content test is carried out to find out how much minerals are contained in a food ingredient. The results of the analysis of ash content contained in yogurt powder products do not meet SNI standards. Ash content contained in yogurt according to SNI maximum 1\% [22] Ash content from F3 fortified yogurt has the highest ash content compared to ash content in F2 and F1 because super red dragon fruit peels contain minerals such as phosphorus.

The $\mathrm{pH}$ measurement is done by using the potentiometric method with a $\mathrm{pH}$ meter. This method was chosen because it is easy, fast, and the results are accurate. The pH yogurt test results can be seen in Figure 2. 


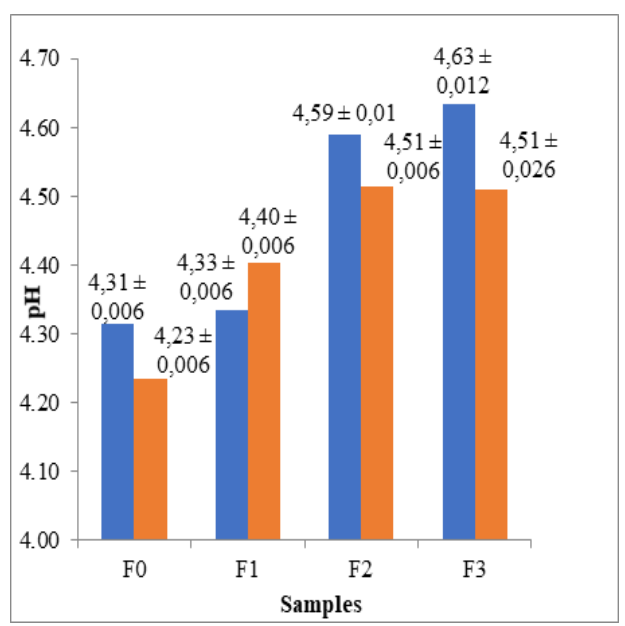

Fig; 2. pH value of fortified yogurt with super red dragon fruit skin powder and without fortification before freeze-drying (blue) and after freeze-drying (red).

A $\mathrm{pH}$ test is performed to determine the acidity of the yogurt powder. The $\mathrm{pH}$ test results for yogurt powder ranged from 4.23 to 4.63 . Based on research conducted by Kenna's yogurt powder obtained has a $\mathrm{pH}$ ranging from 4.01 to 4.16 [15]. The standard $\mathrm{pH}$ value for liquid yogurt ranges from 3.8-4.8 [23]. So that the yogurt powder fortified with super red dragon fruit peel complies with the yogurt $\mathrm{pH}$ standard and has been in the range of $\mathrm{pH}$ values in previous studies. Yogurt has a low $\mathrm{pH}$ because, during the fermentation process, the lactose contained in milk is converted to lactic acid by lactic acid bacteria. The lactic acid that is formed can reduce the $\mathrm{pH}$ value of yogurt. The addition of super red dragon fruit peel causes an increase in the $\mathrm{pH}$ value of the yogurt powder so that the highest $\mathrm{pH}$ of the yogurt powder is found in $\mathrm{F} 3$, followed by F2 and F1.

In Figure 2, it can be seen that the $\mathrm{pH}$ value before freeze-drying is higher when compared to the $\mathrm{pH}$ value after freeze-drying. The $\mathrm{pH}$ of the yogurt powder tends to decrease for $\mathrm{F} 0$. This also occurs in F2 and F3 fortified yogurt while for $\mathrm{F} 1$ the $\mathrm{pH}$ value increases. This shows that the freeze-drying process does not affect the $\mathrm{pH}$ value.

\section{Conclusion}

Produced yogurt without fortification (F0) and three fortified yogurt variants F1, F2 and F3 with $10 \% ; 20 \% ; 30 \%$ successive fortification. The results of the analysis showed super red dragon fruit peels had antioxidant activity $93.08 \% \pm 2.51$; powdered yogurt before fortification $15.86 \% \pm 3.39$ while F1, F2, and F3 fortified powdered yogurt were $63.69 \% \pm 1.70 ; 76.33 \% \pm$ 2.79 and $92.67 \% \pm 1.61$ respectively. The water content of powdered yogurt before fortification was greater than fortified yogurt. The ash content of yogurt before fortification and fortified powdered yogurt are greater than the value of standard ash content. The $\mathrm{pH}$ value of yogurt powder before fortification and fortified yogurt is in the $\mathrm{pH}$ range of yogurt. 


\section{References}

[1] Corrieu, G., Béal, C.: Yogurt: The Product and Its Manufacture.Encyclopedia Food Health,5, 617624. (2016)

[2] Jeantet, R., Croguennec, T., Mahaut, M., Schuck, P., Brulé, G. Les produits laitiers. Editions TEC\&DOC, Paris (2008)

[3] Kumar, P., Mishra, H.N. Yoghurt Powder: A Review of Process Technology, Storage and Utilization. Food Bioprod. Process, 82 (2), 133-142 (2004).

[4] Fellows, P.J. Food Processing Technology-Principals and Practice. Woodhead Publishing Chichester (2009)

[5] USDA United States Departement of Agriculture, National Nutrient Database for Standard Reference. Journal of Agricultural and Food Chemistry. Vol 54(5): pp. 599-603 (2012)

[6] Chouchouli, V., Kalogeropoulos, N., Konteles, S.J., Karvela, E., Makris, D.P.,Karathanos, V.T. Fortification of Yoghurts With Grape (Vitis Vinifera) Seed Extracts. LWT - Food Sci. Technol,53(2), pp. 522-529 (2013)

[7] Panjuantiningrum, F.: Pengaruh Pemberian Buah Naga Merah (Hylocereus polyrhizus) Terhadap Kadar Glukosa Darah Tikus Puth yang Diinduksi Aloksan. (Skripsi). Universitas Sebelas Maret, Surakarta (2009)

[8] Fajriani, Q.H. Penetuan Aktivitas Antioksidan Kulit Buah Naga Super Merah (Hylocereus costaricensis) dan Produk Olahannya Berupa Permen Jelly. (Skripsi). Universitas Pendidikan Indonesia, Bandung (2013).

[9] Wu, L. C., Hsu, H. W., Chen, Y. C., Chiu, C. C., Lin, Y. I., \& Ho, J. A. A.: Antioxidant and Antiproliferative Activities of Red Pitaya. Food Chemistry, 95(2) , pp. 319-327 (2006)

[10 ] Nurliyana, R., Syed Zahir, I., Musthapa Suleiman, K., Aisyah, M. R., \&Kamarul Rahim, K.: Antioxidant Study of Pulps and Peels of Dragon Fruits: A Comparative Study. International Food Research Journal, 17 (2), pp. 367-375 (2010)

[11] Wahyuni, R.: Pemanfaatan Buah Naga Super Merah (Hylocereus costaricensis) Dalam Pembuatan Jenang dengan Perlakuan Penambahan Daging Buah yang Berbeda. Jurnal Teknologi Pangan,4(1) (2012)

[12] Sari, N., dan Rohmah, M.: Pengaruh Formulasi Daging Buah Naga Super Merah(Hylocereus costaricencis) dengan Daging Kelinci Terhadap Sifat Kimia dan Sensoris Nugget.Jurnal Teknologi Pertanian Universitas Mulawarman (2014)

[13] Sangi, M., Runtuwene, M. R., Simbala, H. E., \& Makang, V. M.: Analisis Fitokimia Tumbuhan Obat di Kabupaten Minahasa Utara. Chemistry Progress, 1(1), pp. 47-53 (2008)

[14] Teguh, R. P. K., Nugerahani, I., \& Kusmawati, N.: Pembuatan Yoghurt Buah Naga Merah (Hylocereus Polyrhizus L.): Proporsi Sari Buah dan Susu UHT Terhadap Viabilitas Bakteri dan Keasaman Yoghurt. Jurnal Teknologi Pangan dan Gizi, 14 (2), pp. 89-94 (2015)

[15] Kennas, A., Amellall-Chibane, H., Kessal, F., \& Halladj, F.: Effect of Pomegranate Peel and Honey Fortificationon Physicochemical, Physical, Microbiological and Antioxidant Properties of Yoghurt Powder. Journal of the Saudi Society of Agricultural Sciences (2018)

[16] Garcia, E. J., Oldoni, T. L. C., Alencar, S. M. D., Reis, A., Loguercio, A. D., \& Grande, R. H. M.: Antioxidant Activity by DPPH Assay of Potential Solutions to be Applied on Bleached Teeth. Brazilian dental journal, 23(1), pp. 22-27 (2012)

[17] Badan Standarisasi Nasional. Susu Bubuk (SNI 2970:2015). Jakarta. (2015)

[18] Badan Standarisasi Nasional. Cara Uji Makanan dan Minuman (SNI 01-2891-1992). Jakarta (1992)

[19] AOAC. Official Methods of Analysis of The Association of Official Analytical Chemists. Washington D.C. (1995)

[20] US-FDA, United States Food and Drug Administration. Ultraviolet Radiation For The Processing and Treatment Of Food. Code of Federal Regulations, 21 Part, 179.39 (2002)

[21] Herminiati, A., Rimbawan., Setiawan, B., Astuti, D. A., Udin, L. Z.: Karakteristik Yoghurt Kering yang Diperkaya Difructose Anhydride III Dari Umbi Dahlia Sebagai Minuman Fungsional. AGRITECH.35(2) (2015) 
[22] Badan Standarisasi Nasional Yoghurt (SNI 2981:2009).Jakarta: Badan Standarisasi Nasional (2009)

[23] Jay, J. M., Loessner, M. J., \& Golden, D. A. Indicators of Food Microbial Quality and Safety. Modern Food Microbiology, pp. 473-495 (2005) 